\title{
Induced Mutations in Homozygous and Heterozygous Genotypes of Soybean
}

\author{
H. V. Kalpande, S. B. Borgaonkar* and S. K. Chavan \\ Department of Agril. Botany, \\ Vasantrao Naik Marathwada Krishi Vidyapeeth, Parbhani, (Maharashtra), India \\ *Corresponding author
}

A B S T R A C T

K e y w o r d s
$\begin{aligned} & \text { Frequency and } \\ & \text { spectrum, Gamma } \\ & \text { rays, Homozygous, } \\ & \text { Chlorophyll }\end{aligned}$
Article Info
$\begin{aligned} & \text { Accepted: } \\ & 21 \text { May } 2020 \\ & \text { Available Online: } \\ & \text { 10 June } 2020\end{aligned}$

\section{Introduction}

Soybean (Glycine max (L.) Merrill) is one of the most important oilseed-cum leguminous crop gaining importance during recent years. Importance of soybean in Indian Agriculture is obvious because of its high protein $(42 \%)$ and oil $(20 \%)$ content. In order to induce more variability and utilize useful mutations for efficient plant breeding, comparative assessment of variability generated by hybridization has been reported earlier. The present manuscript, aims to report comparative mutation frequency and spectrum in homozygous and heterozygous genotypes when treated with gamma rays mutagens.

\section{Materials and Methods}

Dry seeds of two Soybean (Glycine max (L.) Merrill) homozygous cultivars, viz., MAUS47 and JS-97-52, along with their $F_{1}$ hybrid (MAUS-47 x JS-97-52) were treated separately with the gamma rays to 10,20 and $30 \mathrm{kR}$ dose of gamma rays $\left(\mathrm{CO}^{60}\right)$ with a dose rate of $2.39 \mathrm{kR}$ per minute at Nuclear and Agriculture Division, B. A. R. C. Trombay, 
Mumbai-400 085 and the same number of untreated seeds of each varieties served as control.

Ten normal looking plants from each treatments in $\mathrm{M}_{1}$ were selected randomly to raise $\mathrm{M}_{2}$ generation. From these, 50 plants per replication were raised in a randomized block design with three replication for each treatment in $\mathrm{M}_{2}$ generation. Normal cultural practices were carefully screened for chlorophyll and morphological mutations. Mutation frequency was calculated as percentage of $\mathrm{M}_{2}$ plants.

\section{Results and Discussion}

The observed morphological and chlorophyll changes in $\mathrm{M}_{2}, \mathrm{~F}_{2} \mathrm{M}_{2}$ are discussed below (Table 1-5).

\section{$\mathbf{M}_{2}, \mathbf{F}_{2} \mathbf{M}_{2}$ generation}

\section{Chlorophyll mutations}

The scoring of chlorophyll mutations in $\mathbf{M}_{2}$, $\mathrm{F}_{2} \mathrm{M}_{2}$ generation has been estimated as one of the most dependable indices for evaluation of genetic effects of mutagenic treatments. The mutagenic effect can be measured in both the terms of quantity and quality by studying the spectrum the frequency of chlorophyll mutations.

Gustafsson (1969) has reviewed the various aspects of directed mutagenesis with particular reference to mutagenic specificity and treatment conditions. He postulated that the use of different mutagens under appropriately modifying treatment conditions could alter relative proportions of different types of mutations and enhance the mutations frequency.

The spectrum of chlorophyll mutation induced by mutagenic treatments was found to vary according to the dose and populations.
The albina, xantha, viridis, xanthaviridis and chlorina mutations were of common occurrence in all three populations. The different mutagens used, differed significantly from each other for inducing chlorophyll mutations. However ethylmethane sulphonate in all the populations were found most effective in inducing chlorophyll mutations than gamma rays.

All three mutagens viz., gamma rays and EMS induced maximum chlorophyll mutations namely albina, xantha, alboviridis, xanthaviridis and chlorophyll. Similar spectrum of chlorophyll mutations was also reported by Amarnath and Prasad (2000) in Tobacco, Geetha and Vaidyanathan (2000), Wakode et al., (2000), Nandanwar et al., (2005), Karthika and Lakshmi (2006), Manjaya (2009), Dhanavel et al., (2012), Magar et al., (2012), Satpute and Fultambkar (2012) and Girija and Dhanavel (2013) in soybean.

The frequency of chlorophyll mutation on $\mathrm{M}_{2}$, $\mathrm{F}_{2} \mathrm{M}_{2}$ family basis were found highest in 20 $\mathrm{kR}$ gamma rays and $0.6 \%$ EMS concentration in all the populations. The similar results were also reported by Dhole (1999), Geetha and Vaidyanathan (2000), Wakode et al., (2000), Bhosale and Hallale (2011) and Makeen et al., (2013).

The induction of chlorophyll mutations may be attributed to changes in structural components of chlorophyll and failure of protoplastid to develop in to plastids with normal size and colour or both (Gustafsson, 1940).

\section{Viable mutations}

The prospects of inducing desirable mutants and usefulness in breeding programme have been encouraging since the time of Stadler (1929, 1930). 
In the present study, the frequency of viable mutations expressed in $\mathrm{M}_{2}, \mathrm{~F}_{2} \mathrm{M}_{2}$ generation was found to increase in doses of both the mutagens. Frequency and spectrum of viable mutations were high in EMS treatments than gamma rays. This is in contradiction to the earlier reports of Veenakumari (1994) and Paul and Singh (2005) who recorded a greater frequency and wider spectrum of viable mutations in populations treated with gamma rays rather than chemical mutagens.

However, superiority of chemical mutagens over radiations causing functional alterations in genes has been described by Makeen et al., (2013) in urd bean.

The various types of viable mutations with altered plant habit were isolated in $\mathrm{M}_{2}$ generation and important ones were confirmed in $\mathrm{M}_{3}, \mathrm{~F}_{3} \mathrm{M}_{3}$ generation of all three soybean populations. Study of spectrum of viable mutations showed that numbers of viable mutations were induced for growth habit followed by leaf and then economic mutations.

Among the population JS-97-52 x MAUS-47 was able to express higher frequency and wider spectrum followed by JS-97-52. Similar finding have been reported by Veenakumari (1994), Amarnath and Prasad (2000), Wakode et al., (2000) this suggests that, mutation production and recovery of desirable mutations seems to be mostly governed by genotypic background of the material treated. The mutations confirmed in $\mathrm{M}_{3}, \mathrm{~F}_{3} \mathrm{M}_{3}$ generation are described below.

\section{Small leaf mutant}

The mutant isolated for leaf character in which the leaf size was reduced up to one third of control. The leaf shape was found to be elongated and narrow. Similar kinds of mutants were also recorded earlier by
Veenakumari (1994) in soybean and Mahadevu (1999) in cowpea.

\section{Broad leaf mutant}

These mutants were having broad leaf size. The leaf area of these mutants was observed from $94.48 \mathrm{sq}$. $\mathrm{cm}$ to $113.08 \mathrm{sq}$. $\mathrm{cm}$ in MAUS-47 and from 91.23 to 119.74 sq. $\mathrm{cm}$ in JS-97-52 x MAUS-47 Pod bearing of these mutants was medium. Similar type of mutants was also noted by Patil (2006) and Kumar et al., (2009).

\section{Multifoliate mutant}

These mutants were isolated in maximum frequency in $0.6 \%$ EMS populations. Mahadevu (1999), Maheshwari et al., (2003) and Kumar et al., (2009).

\section{Unbranch mutant}

Characteristic feature of these mutant were branchless, trifoliate leaves, medium height and low pod setting. Patil (2006) reported these type of mutant in soybean.

\section{Miniature}

These mutants were isolated only in JS-97-52 populations. The height of these mutant was very less. The leaf area was marked by reduced to 10 to 17 sq.cm as against control, 68.50 sq. $\mathrm{cm}$. Similar type of mutant were also reported by Patil (2006) in soybean and Kumar et al., (2009) in urdbean.

\section{High pubescence/Hairy mutant}

These mutants were having prominent red and white dense pubescence on stems and pods. The insect attack was found very negligible on these mutants Darange (2004) and Patil (2006) in soybean reported such type of mutants. 


\section{Bunchy flower mutant}

A very few plants were observed in JS-97-52. The characteristic feature of this mutant is develop flower bunch and not converted to pods. Plant showed luxuriant vegetative growth without reproductive growth. Leaves are quite wider than the normal control populations. Similar type of mutant reported by Nandanwar (1995) in mungbean and Patil (2006) in soybean.

\section{Sterile mutant}

These type of mutant was found in the populations of soybean. Sterility was more pronounced at higher doses and with less frequency in JS-97-52. The characteristic feature of these mutants having more branches and very luxuriant vegetative without reproductive growth. Maximum flower on these mutant plants found to be rudimentary nature. The number of flower and anthers in flower were very less. Dhole (1999), Wakode et al., (2000) and Basavaraja (2002) in soybean, Barshile and Apparao (2009) in chickpea reported these types of mutants.

\section{Economic and other mutant}

On the basis of earliness, seed colour, size, shape, grain yield plant ${ }^{-1}$ the mutations are classified in to early and late, high and low yielding, bold and small podded and seeded and cream seed vs. Verigated colour seeds, less vs. high branches. Early mutations recorded in all the populations, matured 21 to 34 days earlier than control and were short stature.

Table.1 Frequency of chlorophyll mutations in $\mathrm{M}_{2}, \mathrm{~F}_{2} \mathrm{M}_{2}$ generation of soybean populations

\begin{tabular}{|c|c|c|c|c|}
\hline Genotypes & Treatments & $\begin{array}{l}\text { No. of seedlings } \\
\text { scored }\end{array}$ & $\begin{array}{c}\text { No. of } \\
\text { chlorophyll } \\
\text { mutants }\end{array}$ & $\begin{array}{c}\text { Frequency of } \\
\text { chlorophyll } \\
\text { mutations (\%) }\end{array}$ \\
\hline \multirow[t]{7}{*}{ JS- 97- 52} & Control & 1521 & - & - \\
\hline & $10 \mathrm{kR}$ & 1140 & 8 & 0.70 \\
\hline & $20 \mathrm{kR}$ & 1232 & 11 & 0.89 \\
\hline & $30 \mathrm{kR}$ & 1307 & 9 & 0.69 \\
\hline & $0.4 \%$ & 1182 & 7 & 0.59 \\
\hline & $0.6 \%$ & 1042 & 12 & 1.15 \\
\hline & $0.8 \%$ & 1218 & 10 & 0.82 \\
\hline \multirow[t]{7}{*}{ MAUS - 47} & Control & 1422 & - & - \\
\hline & $10 \mathrm{kR}$ & 1159 & 5 & 0.43 \\
\hline & $20 \mathrm{kR}$ & 1041 & 11 & 1.06 \\
\hline & $30 \mathrm{kR}$ & 1266 & 14 & 1.10 \\
\hline & $0.4 \%$ & 1123 & 4 & 0.36 \\
\hline & $0.6 \%$ & 1294 & 10 & 0.77 \\
\hline & $0.8 \%$ & 1214 & 12 & 0.98 \\
\hline \multirow{7}{*}{$\begin{array}{l}\text { JS- 97- } 52 \text { x MAUS } \\
-47\end{array}$} & Control & 1289 & - & - \\
\hline & $10 \mathrm{kR}$ & 1017 & 7 & 0.69 \\
\hline & $20 \mathrm{kR}$ & 1148 & 12 & 1.04 \\
\hline & $30 \mathrm{kR}$ & 1254 & 15 & 1.20 \\
\hline & $0.4 \%$ & 1178 & 9 & 0.76 \\
\hline & $0.6 \%$ & 1036 & 10 & 0.96 \\
\hline & $0.8 \%$ & 1139 & 14 & 1.22 \\
\hline
\end{tabular}


Table.2 Spectrum of chlorophyll mutations in $\mathrm{M}_{2}, \mathrm{~F}_{2} \mathrm{M}_{2}$ generation of soybean populations

\begin{tabular}{|c|c|c|c|c|c|c|c|}
\hline \multirow[t]{2}{*}{ Genotypes } & \multirow[t]{2}{*}{ Treatments } & \multicolumn{5}{|c|}{ Chlorophyll mutants } & \multirow[t]{2}{*}{ Total } \\
\hline & & Albina & Xantha & Chlorina & Viridis & Xanthviridis & \\
\hline \multirow[t]{7}{*}{ JS- 97- 52} & Control & - & - & - & - & - & - \\
\hline & $10 \mathrm{kR}$ & - & 1 & 3 & 2 & 1 & 7 \\
\hline & $20 \mathrm{kR}$ & 3 & 2 & 2 & 3 & - & 10 \\
\hline & $30 \mathrm{kR}$ & 2 & 2 & 3 & 4 & - & 11 \\
\hline & $0.4 \%$ & - & 1 & 1 & 3 & - & 5 \\
\hline & $0.6 \%$ & - & 2 & 3 & 5 & 2 & 12 \\
\hline & $0.8 \%$ & 1 & 2 & 4 & 6 & - & 13 \\
\hline \multirow[t]{7}{*}{ MAUS - 47} & Control & - & - & - & - & - & - \\
\hline & $10 \mathrm{kR}$ & - & 1 & 2 & 1 & 2 & 6 \\
\hline & $20 \mathrm{kR}$ & - & 1 & 4 & 1 & - & 6 \\
\hline & $30 \mathrm{kR}$ & - & 5 & 3 & 2 & - & 10 \\
\hline & $0.4 \%$ & - & - & 5 & 3 & - & 8 \\
\hline & $0.6 \%$ & 1 & 3 & 3 & 4 & - & 11 \\
\hline & $0.8 \%$ & 2 & 2 & 3 & 4 & 1 & 12 \\
\hline \multirow{7}{*}{$\begin{array}{l}\text { JS- 97- } 52 \text { x MAUS - } \\
47\end{array}$} & Control & - & - & - & - & - & - \\
\hline & $10 \mathrm{kR}$ & 1 & 2 & 1 & 2 & - & 4 \\
\hline & $20 \mathrm{kR}$ & - & 1 & 6 & 2 & 2 & 11 \\
\hline & $30 \mathrm{kR}$ & 3 & 2 & 3 & 4 & - & 12 \\
\hline & $0.4 \%$ & - & 1 & 2 & 3 & - & 6 \\
\hline & $0.6 \%$ & 1 & 2 & 2 & 8 & 1 & 14 \\
\hline & $0.8 \%$ & - & 3 & 4 & 6 & - & 12 \\
\hline
\end{tabular}


Table.3 Mutagenic effectiveness and efficiency of mutagens in inducing chlorophyll mutations in soybean populations

\begin{tabular}{|c|c|c|c|}
\hline Genotypes & Treatments & Mutagenic effectiveness (\%) & Mutagenic efficiency (\%) \\
\hline \multirow[t]{7}{*}{ JS- 97- 52} & Control & - & - \\
\hline & $10 \mathrm{kR}$ & 7 & 5.23 \\
\hline & $20 \mathrm{kR}$ & 4.45 & 4.01 \\
\hline & $30 \mathrm{kR}$ & 2.3 & 2.16 \\
\hline & $0.4 \%$ & 18.43 & 4.97 \\
\hline & $0.6 \%$ & 25.83 & 7.91 \\
\hline & $0.8 \%$ & 12.81 & 3.66 \\
\hline \multirow[t]{7}{*}{ MAUS - 47} & Control & - & - \\
\hline & $10 \mathrm{kR}$ & 4.30 & 4.44 \\
\hline & $20 \mathrm{kR}$ & 5.75 & 8.36 \\
\hline & $30 \mathrm{kR}$ & 3.43 & 4.60 \\
\hline & $0.4 \%$ & 11.25 & 2.77 \\
\hline & $0.6 \%$ & 16.04 & 3.91 \\
\hline & $0.8 \%$ & 15.31 & 4.34 \\
\hline \multirow[t]{7}{*}{ JS- 97- 52 x MAUS - 47} & Control & - & - \\
\hline & $10 \mathrm{kR}$ & 6.9 & 4.19 \\
\hline & $20 \mathrm{kR}$ & 5.65 & 4.85 \\
\hline & $30 \mathrm{kR}$ & 2.93 & 2.98 \\
\hline & $0.4 \%$ & 23.75 & 5.74 \\
\hline & $0.6 \%$ & 20.00 & 6.24 \\
\hline & $0.8 \%$ & 19.06 & 4.68 \\
\hline
\end{tabular}


Table.4 Frequency of viable mutations in $\mathrm{M}_{2}, \mathrm{~F}_{2} \mathrm{M}_{2}$ generation of soybean populations

\begin{tabular}{|c|c|c|c|c|}
\hline Genotypes & Treatments & $\begin{array}{c}\text { No. of seedlings } \\
\text { scored }\end{array}$ & $\begin{array}{c}\text { No. of viable } \\
\text { mutants }\end{array}$ & $\begin{array}{c}\text { Frequency of viable } \\
\text { mutations }(\%)\end{array}$ \\
\hline \multirow[t]{7}{*}{ JS- 97- 52} & Control & 1521 & - & - \\
\hline & $10 \mathrm{kR}$ & 1140 & 10 & 0.89 \\
\hline & $20 \mathrm{kR}$ & 1232 & 19 & 1.54 \\
\hline & $30 \mathrm{kR}$ & 1307 & 26 & 1.99 \\
\hline & $0.4 \%$ & 1182 & 13 & 1.10 \\
\hline & $0.6 \%$ & 1042 & 22 & 2.11 \\
\hline & $0.8 \%$ & 1218 & 21 & 1.72 \\
\hline \multirow[t]{7}{*}{ MAUS - 47} & Control & 1422 & - & - \\
\hline & $10 \mathrm{kR}$ & 1159 & 12 & 1.04 \\
\hline & $20 \mathrm{kR}$ & 1041 & 18 & 1.73 \\
\hline & $30 \mathrm{kR}$ & 1266 & 16 & 1.26 \\
\hline & $0.4 \%$ & 1123 & 15 & 1.33 \\
\hline & $0.6 \%$ & 1294 & 32 & 2.47 \\
\hline & $0.8 \%$ & 1214 & 26 & 2.14 \\
\hline \multirow[t]{7}{*}{ JS- 97- 52 x MAUS - 47} & Control & 1289 & - & - \\
\hline & $10 \mathrm{kR}$ & 1017 & 14 & 1.38 \\
\hline & $20 \mathrm{kR}$ & 1148 & 16 & 1.39 \\
\hline & $30 \mathrm{kR}$ & 1254 & 28 & 2.23 \\
\hline & $0.4 \%$ & 1178 & 21 & 1.78 \\
\hline & $0.6 \%$ & 1036 & 30 & 2.90 \\
\hline & $0.8 \%$ & 1139 & 29 & 2.55 \\
\hline
\end{tabular}


Table.5 Spectrum of viable mutations in $\mathrm{M}_{2}, \mathrm{~F}_{2} \mathrm{M}_{2}$ generation of soybean populations

\begin{tabular}{|c|c|c|c|c|c|c|c|c|c|c|c|}
\hline \multirow[t]{2}{*}{ Genotypes } & \multirow[t]{2}{*}{ Treatments } & \multicolumn{3}{|c|}{ Leaf mutant } & \multicolumn{4}{|c|}{ Growth habit mutant } & \multicolumn{3}{|c|}{ Other mutants } \\
\hline & & $\begin{array}{l}\text { Narrow } \\
\text { leaves }\end{array}$ & $\begin{array}{c}\text { Broad } \\
\text { leaf }\end{array}$ & $\begin{array}{c}\text { Multifoliate } \\
\text { leaf }\end{array}$ & $\begin{array}{l}\text { Dwarf } \\
\text { bushy }\end{array}$ & $\begin{array}{c}\text { Tall } \\
\text { erect }\end{array}$ & Unbranch & miniature & $\begin{array}{c}\text { Changed } \\
\text { flower } \\
\text { colour }\end{array}$ & $\begin{array}{c}\text { High } \\
\text { pubesence }\end{array}$ & $\begin{array}{l}\text { Bunchy } \\
\text { flower }\end{array}$ \\
\hline \multirow[t]{7}{*}{ JS - 97 - 52} & Control & 0 & 0 & 0 & 0 & 0 & 0 & 0 & 0 & 0 & 0 \\
\hline & $10 \mathrm{kR}$ & - & 1 & - & 2 & 3 & - & 2 & 2 & - & 1 \\
\hline & $20 \mathrm{kR}$ & 2 & - & 1 & 1 & - & - & - & - & - & - \\
\hline & $30 \mathrm{kR}$ & 9 & - & - & 2 & 1 & - & 1 & - & - & - \\
\hline & $0.4 \%$ & 2 & - & 1 & 9 & 4 & - & - & 2 & 2 & - \\
\hline & $0.6 \%$ & 8 & - & 2 & 6 & 1 & - & 1 & 4 & - & - \\
\hline & $0.8 \%$ & 4 & - & - & 5 & - & - & - & - & - & 2 \\
\hline \multirow[t]{7}{*}{ MAUS - 47} & Control & 0 & 0 & 0 & 0 & 0 & 0 & 0 & 0 & 0 & 0 \\
\hline & $10 \mathrm{kR}$ & 1 & 1 & - & 2 & 1 & 8 & - & - & - & - \\
\hline & $20 \mathrm{kR}$ & 4 & - & - & 5 & 3 & 7 & - & - & - & - \\
\hline & $30 \mathrm{kR}$ & 3 & 3 & 1 & - & - & 2 & - & - & - & - \\
\hline & $0.4 \%$ & 2 & - & 1 & 2 & 3 & 12 & - & - & 1 & 3 \\
\hline & $0.6 \%$ & 7 & 1 & 1 & 14 & 1 & 10 & - & - & - & - \\
\hline & $0.8 \%$ & - & 2 & 4 & 1 & 3 & - & - & - & 2 & 2 \\
\hline \multirow{7}{*}{$\begin{array}{l}\text { JS- 97- } 52 \text { x } \\
\text { MAUS - } 47\end{array}$} & Control & 0 & 0 & 0 & 0 & 0 & 0 & 0 & 0 & 0 & 0 \\
\hline & $10 \mathrm{kR}$ & 2 & - & 1 & 3 & 1 & - & - & - & - & 1 \\
\hline & $20 \mathrm{kR}$ & 3 & - & - & 1 & 1 & 4 & 1 & - & 3 & - \\
\hline & $30 \mathrm{kR}$ & 2 & 2 & 1 & - & 3 & 1 & - & - & 2 & 4 \\
\hline & $0.4 \%$ & 3 & 12 & - & 9 & 7 & - & - & - & - & - \\
\hline & $0.6 \%$ & - & 2 & - & 3 & 2 & 8 & - & - & - & - \\
\hline & $0.8 \%$ & 1 & - & 6 & 7 & - & 13 & - & - & - & - \\
\hline
\end{tabular}


Table.5 Contd............

\begin{tabular}{|c|c|c|c|c|c|c|c|c|c|c|c|}
\hline \multirow[t]{2}{*}{ Genotypes } & \multirow[t]{2}{*}{ Treatments } & \multicolumn{4}{|c|}{ Other mutants } & \multicolumn{5}{|c|}{ Economic mutant } & \multirow{2}{*}{$\begin{array}{c}\text { Total } \\
\text { mutants }\end{array}$} \\
\hline & & sterile & $\begin{array}{c}\text { Small } \\
\text { podded \& } \\
\text { seeded }\end{array}$ & $\begin{array}{l}\text { Deformed } \\
\text { pod }\end{array}$ & $\begin{array}{l}\text { Verigated } \\
\text { seed } \\
\text { colour }\end{array}$ & $\begin{array}{c}\text { Early } \\
\text { maturing }\end{array}$ & $\begin{array}{c}\text { Late } \\
\text { maturing }\end{array}$ & $\begin{array}{c}\text { High } \\
\text { branching }\end{array}$ & $\begin{array}{c}\text { Big } \\
\text { podded } \\
\text { \& bold } \\
\text { seeded }\end{array}$ & $\begin{array}{c}\text { Non } \\
\text { shattering }\end{array}$ & \\
\hline \multirow[t]{7}{*}{ JS- 97- 52} & Control & 0 & 0 & 0 & 0 & 0 & 0 & & 0 & 0 & 0 \\
\hline & $10 \mathrm{kR}$ & - & 5 & - & - & 3 & 5 & 3 & 2 & 3 & 32 \\
\hline & $20 \mathrm{kR}$ & 1 & 12 & - & - & 1 & - & - & 4 & 9 & 31 \\
\hline & $30 \mathrm{kR}$ & 1 & 2 & - & 1 & - & - & - & - & 7 & 24 \\
\hline & $0.4 \%$ & 2 & - & 2 & - & 2 & 6 & 4 & 2 & 10 & 48 \\
\hline & $0.6 \%$ & - & 4 & 1 & - & 4 & 3 & 8 & 4 & 8 & 54 \\
\hline & $0.8 \%$ & 3 & 10 & - & 1 & 2 & 3 & 5 & 3 & 14 & 52 \\
\hline \multirow[t]{7}{*}{ MAUS - 47} & Control & 0 & 0 & 0 & 0 & 0 & 0 & 0 & 0 & 0 & 0 \\
\hline & $10 \mathrm{kR}$ & 1 & - & 1 & - & 7 & 3 & 2 & 3 & - & 30 \\
\hline & $20 \mathrm{kR}$ & 5 & 2 & - & - & 4 & 5 & 1 & 6 & 3 & 45 \\
\hline & $30 \mathrm{kR}$ & 1 & - & - & - & - & 2 & 3 & 9 & 4 & 28 \\
\hline & $0.4 \%$ & - & 1 & - & - & 2 & 2 & - & 1 & 1 & 31 \\
\hline & $0.6 \%$ & 4 & - & 1 & - & - & - & 3 & 7 & 5 & 54 \\
\hline & $0.8 \%$ & 2 & 1 & - & - & 2 & - & - & - & 3 & 22 \\
\hline \multirow{7}{*}{$\begin{array}{l}\text { JS- 97- } 52 \text { x } \\
\text { MAUS - } 47\end{array}$} & Control & 0 & 0 & 0 & 0 & 0 & 0 & 0 & 0 & 0 & 0 \\
\hline & $10 \mathrm{kR}$ & 1 & 6 & - & - & 3 & 2 & 1 & 3 & 2 & 26 \\
\hline & $20 \mathrm{kR}$ & 5 & 3 & 2 & 1 & 3 & 6 & 6 & 10 & 7 & 53 \\
\hline & $30 \mathrm{kR}$ & 1 & 1 & - & 1 & 7 & 2 & 3 & 5 & 7 & 42 \\
\hline & $0.4 \%$ & 3 & 3 & 1 & - & 13 & 1 & - & - & 3 & 55 \\
\hline & $0.6 \%$ & 7 & 9 & 4 & - & 2 & 10 & 7 & 7 & 7 & 66 \\
\hline & $0.8 \%$ & 4 & 1 & 2 & 1 & 5 & - & 10 & 9 & 10 & 69 \\
\hline
\end{tabular}


Late maturing recorded 20 to 25 days delayed maturity as compared to control. High yielding mutants were medium tall, healthy, with increase pod bearing branches, pod number and grain yield. High yielder recorded double grain yield as compared to control plant. Some of these mutants bred true in $\mathrm{M}_{3}$, $\mathrm{M}_{3} \mathrm{~F}_{3}$ generation. Some other types of mutants like long and small podded, deformed pod, high branching, non-shattering of pod, small and bold seeded, Verigated seed shape and colour isolated in all the populations in $\mathrm{M}_{2}$, $\mathrm{F}_{2} \mathrm{M}_{2}$ generation, Makeen et al., (2013) in urd bean, and Ahire et al., (2005) and Patil (2006) reported this type of mutant in soybean.

\section{Mutagenic effectiveness and efficiency}

Mutagenic effectiveness is a measure of the frequency of mutations induced by a unit dose of mutagen while mutagenic efficiency is the proportion of mutations in relation to other associated undesirable changes such as lethality, and sterility (Konzak et al., 1965) induced by a mutagen.

The usefulness of any mutagen in plant breeding depends not only on its mutagenic effectiveness but also on its mutagenic efficiency. Efficient mutagenesis is the production of desirable changes with minimum undesirable changes.

The efficiency of a mutagenic agent is a complex question as it not only depends on the agent with the material and on its applicability to the biological system but also on the degree to which physiological damage, chromosomal aberrations and sterility is induced in addition to mutations.

In the present investigation, in general lower doses of both the mutagens were effective in producing chlorophyll mutations indicating that increase in chlorophyll mutations frequency was not proportional to the increase in dose. Among the two mutagens tried, EMS was highly effective compared to gamma rays. This is in conformity with the reports of Konzak et al., (1965) in barley, Veenakumari (1994) in soybean.

The estimates of mutagenic efficiency in general indicated that the efficiency of EMS was more compared to gamma rays in JS-97$52 \times$ MAUS-47 and JS-97-52. This is in accordance with the finding of Konzak et al., (1965) in lathyrus, Amarnath and Prasad (2000) in tobacco, Patil (2006) in soybean. Contrary to this, gamma rays showed more efficiency in MAUS-47, which is similar to the finding of Nandanwar and Khamankar (1996) and Gautam et al., (1998) who reported that the efficiency of same mutagen varied in different genotypes of urd bean, Pavadai et al., (2010), Satpute and Fultambkar (2012) in soybean.

\section{References}

Ahire, D.D., R.J. Thengane, J.G. manjaya, M. George, and S.V. Bhide (2005). Induced mutations in Soybean (Glycine max (L.) Merrill) cv. MACS 450. Soy. Res. 3:1-8.

Amarnath, S. and A.B. Prasad (2000). Induced mutations in homozygous and terozygous genotypes of tobacco. Ind. J. Genet. 60(2): 171-176.

Barshile, J.D. and B.J. Apparao (2009). Genetic improvement of chickpea (Cicer arietinum L.) using induced mutations. Induced plant mutation in the genomics era. Food Agric. Org. United Nations, Rome, pp. 91-94.

Basavaraja, G.T. (2002). Studies on induced mutagenesis in soybean (Glycine max (L.) Merill). Ph.D. Thesis unpub. Univ. Agril. Sci. Dharwad.

Bhosale, U.P. and B.V. Hallele (2011). Gamma radiation induced mutations in black gram (Vigna mungo (L.) Hepper). Asian J. Plt. Res. 1(2): 96-100. 
Darange, G.O. (2004). Mutagenesis studies in soybean. Ph.D. Thesis unpub. Amravati Univ. Amravati.

Dhanavel, D., S. Gnanamurthy, P. Pavadai, T. Bharathi and R. Thirumal (2012). induction of yield, bicochemical and genetic variability by using gamma rays on soybean (Glycine max (L.) Merril) Int. J. Res. Biol. Sci. 2(3): 113-115.

Dhole, V.J. (1999). Studies on effect of mutagens in soybean. (Glycine max (L) Merrill). M.Sc. Thesis submitted to Dr. PDKV, Akola, pp-82.

Geetha, K. and P. Vaidyanathan (2000). Studies on induction of chlorophyll mutations in soybean (Glycine max L.) through physical and chemical mutagen. Agril. Sci. Digest. 20(1): 33-35.

Geetha, K. and P. Vaidyanathan (2000). Studies on induction of chlorophyll mutations in soybean (Glycine max L.) through physical and chemical mutagen. Agril. Sci. Digest. 20(1): 33-35.

Girija, M. and D. Dhanavel (2013). Effect of gamma rays on quantitative traits of cowpea in $\mathrm{M}_{1}$ generation. Int. J. Res. Biol. Sci. 3(2): 84-87.

Gustafsson, A. (1940). The mutation systems of chlorophyll apparatus. Lands Univ. Arsska N.R. Acad. 36: 1-40.

Gustafsson, A. (1969). A study of induced mutations in plant- Introductory Address. In: Induced mutations in plants. IAEA Vienna, pp. 9-31.

Karthika, R. and B.S. Lakshmi (2006). Effect of gamma rays and EMS on two varieties of soybean. Asian J. Plt. Sci. 5(4): 721-724.

Konzak, C.F., R.A. Nilan, J. Wagner and R.J. Foster (1965). Efficient chemical mutagenesis. Rad. Bot. (Suppl.). 5: 4970 .

Kumar, V., A.K. Sharma, V.P. Singh and M. Kumar (2009). Characterization of prebreeding genetic stocks of urdbean (Vigna mungo L. Hepper) induced through mutagenesis. Induced plant mutation in the genomics era. Food Agric. Org. United Nations, Rome, pp. 391-394.

Magar, S.P., S.E. Mahamune and V.S. Kothekar (2012). Chemical mutagenesis in soybean (Glycine max. L. Merill). Bioinfolet, 9(4A): 542-543.

Mahadevu, P. (1999). Induced mutagenesis for enhanced yield and nitrogen fixing ability in cowpea. (Vigna unguiculata (L.) Walp.) Mysore J. Agric. Sci. 33(3): 286-287.

Maheshwari, J.J., V.J. Dhole, S. Patil and D.R. Rathod (2003). Radiation induced variability for quantitative characters in soybean. J. Soils and Crops. 13(2): 314316.

Makeen, K., B.G. Syresh, G.R. Lavanya and A. Kumari (2013): Study of chlorophyll and macromutations induced by gamma rays and sodium azide in urd bean (Vigna mungo L. Hepper). African J. Agril. Res. 8(47): 5958-5961.

Manjaya, J.G. (2009). Genetic improvement of soybean variety vls-2 through induced mutations. Induced Plt. Mutations in the Genomics Era. Food and Agric. Org. United Nations, Rome, 106-110.

Nandanwar, R.S. and Y.G. Khamankar (1996). Induced variability for quantitative characters in mung bean (Vigna radiata (L.)Wilczek) in $\mathrm{M}_{1}$ generation. In. Proc. of seminar on strategies for increasing pulses production in Maharashtra, 7-8 March at PDKV, Akola.

Nandanwar, R.S., P.Y. Sontake and D.T. Dhule (2005). Radiation induced mutagenesis in soybean (Glycine max. (L.) Merill). In. Abst $4^{\text {th }}$ Inter. Food Legume Res. Conference, 18-22, Oct. New Delhi, pp.186.

Patil, A.N. (2006). Studies on the effect of physical and chemical mutagens on 
some quantitative and qualitative parameters in soybean (Glycine max. (L.) Merill). Ph.D. Thesis unpub. Dr.PDKV, Akola.

Pavadai, P., M. Girija and D. Dhanvel (2010). Effect of gamma-rays on some yield parameter and protein content of soybean in $\mathrm{M}_{2}, \mathrm{M}_{3}$ and $\mathrm{M}_{4}$ generation. J. Experimental Sci. 1: 8-11.

Satpute, R.A. and R.V. Fultambkar (2012). Effect of mutagenesis on germination, survival and pollen sterility in $\mathrm{M}_{1}$ generation of soybean (Glycine max (L.) Merill). Internat. J. Resent Trends in Sci. Tech. 2(3): 30-32.

Stadler, L.J. (1929). Mutation in barley induced by x-rays and radium. Sci. 68: 186.

Stadler, L.J. (1930). Some genetic effects of X-rays in plants. J.Heredity. 21: 3-19.

Veenakumari, K. (1994). Studies on the effect gamma rays and EMS on yield and yield components in soybean (Glycine $\max ($ L.) Merill). M.Sc. (Agri) Thesis, Univ. Agril. Sci. Banglore.

Wakode, M.M., R.S. Nandanwar and G.P. Patil (2000). Radiation induced mutagenesis in soybean (Glycine max (L.) Merill) In. Proc. DAE-BRNS symp. On the use of Nuclear and Molecular Tech. in crop Improv. 6-8 Dec. BARC Mumbai pp. 111-116.

\section{How to cite this article:}

Kalpande, H. V., S. B. Borgaonkar and Chavan, S. K. 2020. Induced Mutations in Homozygous and Heterozygous Genotypes of Soybean. Int.J.Curr.Microbiol.App.Sci. 9(06): 3045-3056. doi: https://doi.org/10.20546/ijcmas.2020.906.366 